\title{
ASSESSING THE VIABILITY OF PROTECTING COLOMBIAN CARIBBEAN COAST FROM SEA LEVEL RISE: AN ECONOMIC VALUATION APPROACH
}

\author{
Andrea Cardoso $0^{* *}$ \\ James Benhin ${ }^{* * *}$ \\ Recibido: agosto 30 de 2010 \\ Aceptado: septiembre 19 de 2011
}

\begin{abstract}
The coastal areas of Colombia are highly susceptible to sea level rise (SLR) due to climate change. The degree of vulnerability has been determined and currently an adaptation plan is being evaluated. This study applied a Cost Benefit Analysis (CBA) over a 100 years scenario to assess the feasibility of the plan in the Colombian Caribbean Coast. A Contingent Valuation Method was used to estimate the market and the non-market benefits, using a random sample of 504 respondents in Barranquilla, Cartagena and Santa Marta. The estimated benefits are weighted against the cost of the protection strategy as estimated by the Netherlands Climate Change Studies Assistance Programme. The CBA results indicate that carrying out the additional measures for protecting the Colombian Caribbean Coast from SLR is an economic and ecological feasible venture even if predictions of SLR are uncertain.
\end{abstract}

\section{KEY WORDS}

Valuation of environmental effects; environmental economics; climate change; sea level rise.

\section{JEL CLASSIFICATION}

Q51; Q54

\section{CONTENT}

1. Introduction and background; 2. Methodology; 3. Results and discussion; 4. Conclusions; References.

Research project. European Joint Master in Water and Coastal Management's dissertation. School of Earth, Ocean and Environmental Sciences. University of Plymouth. Plymouth, United Kingdom. Erasmus Mundus Program. September 2007-March 2008.

* Economist, Universidad Javeriana, Bogotá Colombia. MSc in Water and Coastal Management University of Plymouth. Plymouth, United Kingdom. Full time Professor at the University of Magdalena, Santa Marta, Colombia. Socio-ecologic systems for Human Welfare Research Group. Carrera 32 \# 22-08, Santa Marta, Colombia. Email: acardoso@unimagdalena.edu.co.

".. Economist, University of Cape Coast, Ghana. Mhil in Economics, University of Ghana, Accra, Ghana. PhD in Economics and Environmental Management, University of York. York, United Kingdom. Lecturer at the School of Management, University of Plymouth. Drake Circus, Plymouth, PL4 8AA, United Kingdom. Email: james.benhin@plymouth.ac.uk. 


\section{AVALIAÇÃO DA VIABILIDADE PARA A PROTEÇÃO DO LITORAL CARIBE COLOMBIANO DAS SUBIDAS DO NÍVEL DO MAR: UM ENFOQUE DE VALORAÇÃO ECONÔMICA}

\section{RESUMO}

As áreas do litoral colombiano são altamente susceptíveis as subidas do nível do mar (SNM) por causa das alterações climáticas. O nível de vulnerabilidade tem sido determinado e atualmente um plano de adaptação esta sendo avaliado. Este artigo usa uma Analise Custo Beneficio (ACB) sobre um cenário para avaliar a factibilidade do plano no Litoral Caribe Colombiano. Um método de Valoração Contingente foi usado para estimar os benefícios do mercado e do não-mercado, usando uma mostra aleatória de 504 inquiridos em Barranquilla, Cartagena, e Santa Marta. Os benefícios estimados são comparados contra o custo da estratégia de proteção estimada pelo Programa de Estudos de Assistência de Alterações Climáticas da Holanda. Os resultados ACB indicam que implementar as medidas adicionais para a proteção do Litoral Caribe Colombiano das SNM é um projeto viável, inclusive se as predições das SNM sejam incertas.

\section{PALAVRAS-CHAVE}

Valoração de efeitos no médio ambiente: economia do médio ambiente; alterações climáticas, subidas do nível do mar

\section{CLASSIFICAÇÃO JEL} Q51; Q54

\section{CONTEÚDO}

1. Introdução e entorno; 2. Metodologia; 3. Resultados e discussão; 4. Conclusões e referencias.

\section{EVALUACIÓN DE VIABILIDAD PARA LA PROTECCIÓN DE LA COSTA CARIBE COLOMBIANA DE AUMENTOS EN EL NIVEL DEL MAR: UN ENFOQUE DE VALORACIÓN ECONÓMICA \\ RESUMEN}

Las áreas costeras de Colombia son altamente susceptibles a aumentos en el nivel del mar (ANM) debido al cambio climático. El grado de vulnerabilidad ha sido determinado y actualmente un plan de adaptación está siendo evaluado. Este estudio utilizó un Análisis Costo Beneficio (ACB) sobre un escenario de 100 años para evaluar la factibilidad del plan en la Costa Caribe Colombiana. El Método de Valoración Contingente fue utilizado para estimar los beneficios del mercado y del no-mercado, utilizando una muestra aleatoria de 504 encuestados en Barranquilla, Cartagena y Santa Marta. Los beneficios estimados son comparados contra el costo de la estrategia de protección estimado por el Programa de Estudios de Asistencia de Cambio Climático de Holanda. Los resultados del ACB indican que implementar las medidas adicionales para la protección de la Costa Caribe Colombiana del ANM es un proyecto viable inclusive sí las predicciones del ANM son impredecibles.

\section{PALABRAS CLAVE}

Valoración de efectos medioambientales: economía medioambiental; cambio climático: aumentos en el nivel del mar

\section{CLASIFICACIÓN JEL} Q51; Q54

\section{CONTENIDO}

1. Introducción y entrono; 2. Metodología; 3. Resultados y discusión; 4. Conclusiones; Referencias 


\section{INTRODUCTION AND BACKGROUND}

\subsection{The SLR Impacts in Colombia}

Developing countries like Colombia which have some of the lowest emissions of $\mathrm{CO}_{2}$ globally (between 0.2 and $0.3 \%$ of greenhouse gases global emissions) would however be highly vulnerable to the effects of climate change especially with respect to sea level rise (SLR). An increase of one meter in the average sea level in the region, for instance, would result in a permanent flooding of $4,900 \mathrm{~km}^{2}$ of low-lying coastal areas, with strong pool formation in nearby areas of bodies of water located in the coastal areas, to a complete flooding of $5,100 \mathrm{~km}^{2}$ (IDEAM, 2001). In addition, flooding would increase the rate of erosion, especially in areas where anthropogenic impacts have reduced the buffer capabilities of the coastal systems such as beaches and marshes (INVEMAR, 2003).

Colombia's First National Communication to the United Nation Framework Convention on Climate Change concluded that on the Caribbean coast $49 \%$ of the 7,208,299 hectares of crops were highly vulnerable. In the industrial sector, $75.3 \%$ (475 hectares) of the area used for manufacturing facilities in Barranquilla and 99.7\% (877 hectares) in Cartagena are under high-vulnerability. Moreover, $44.8 \%$ of the road networks were highly vulnerable, $5.2 \%$ are moderately vulnerable and $22.7 \%$ are slightly vulnerable (IDEAM, 2001). These potential impacts and associated economic costs will result in significant challenges for Colombia's environmental management. Consequently, urgent environmental and socio-economic measures must be taken to mitigate the impacts of SLR and to provide sustainable development in the area.

Following these vulnerability assessments of the Colombia coastal area to SLR, e critical areas have been identified by the Colombian National Institute for Marine and Coastal Research (INVEMAR, 2003) under the project: "Netherlands Climate Change Studies Assistance Programme-
(NCCSAP: Colombia): Defining the vulnerability of bio-geophysical and socio-economic systems due to sea level change in the Colombian coastal zone (Pacific and Caribbean) and adaptation measures." A multi-criteria analysis also established the most suitable protection strategy for each hot spot area. Most of the strategies directly addressed the potential flooding problem (see Table 1).

What is lacking is an evaluation of the feasibility of the adaptation plan to help policy makers decide if it should be implemented. This study attempts to assess the viability of the protection plan. Using a CBA approach, CVM estimated benefits was weighed against the estimated cost of the protection strategy using secondary data from the NCCSAP study. The outcome provides an economic framework to assess the adaptation strategies to the SLR and climate change by integrating CBA and economic valuation. This integration implies the assessment of the adaptation strategy itself and the non-market values related with it.

\subsection{The economics of the climate change and SLR}

Several studies have been undertaken to analyse the physical process of climate change impacts, but only since the 1990s have scientists explored the economic impacts of these changes. Gambarelli and Goria (2004) attribute this delay to two main factors. First, economic valuation requires a precise knowledge of the physical impacts; but this knowledge is limited since the climate change process from anthropogenic emissions is still uncertain, because of the large temporal lag between causes and effects. Second, valuing nonmarketable goods by using monetary units can be a difficult and controversial task. Nevertheless, economic assessment studies serve as a tool for policy makers to measure climate change phenomenon from an economic perspective, as well as to obtain information about the economic responses in terms of costs, benefits, equity, efficacy and social feasibility. 
Table 1. Planning stages of the Action Plan.

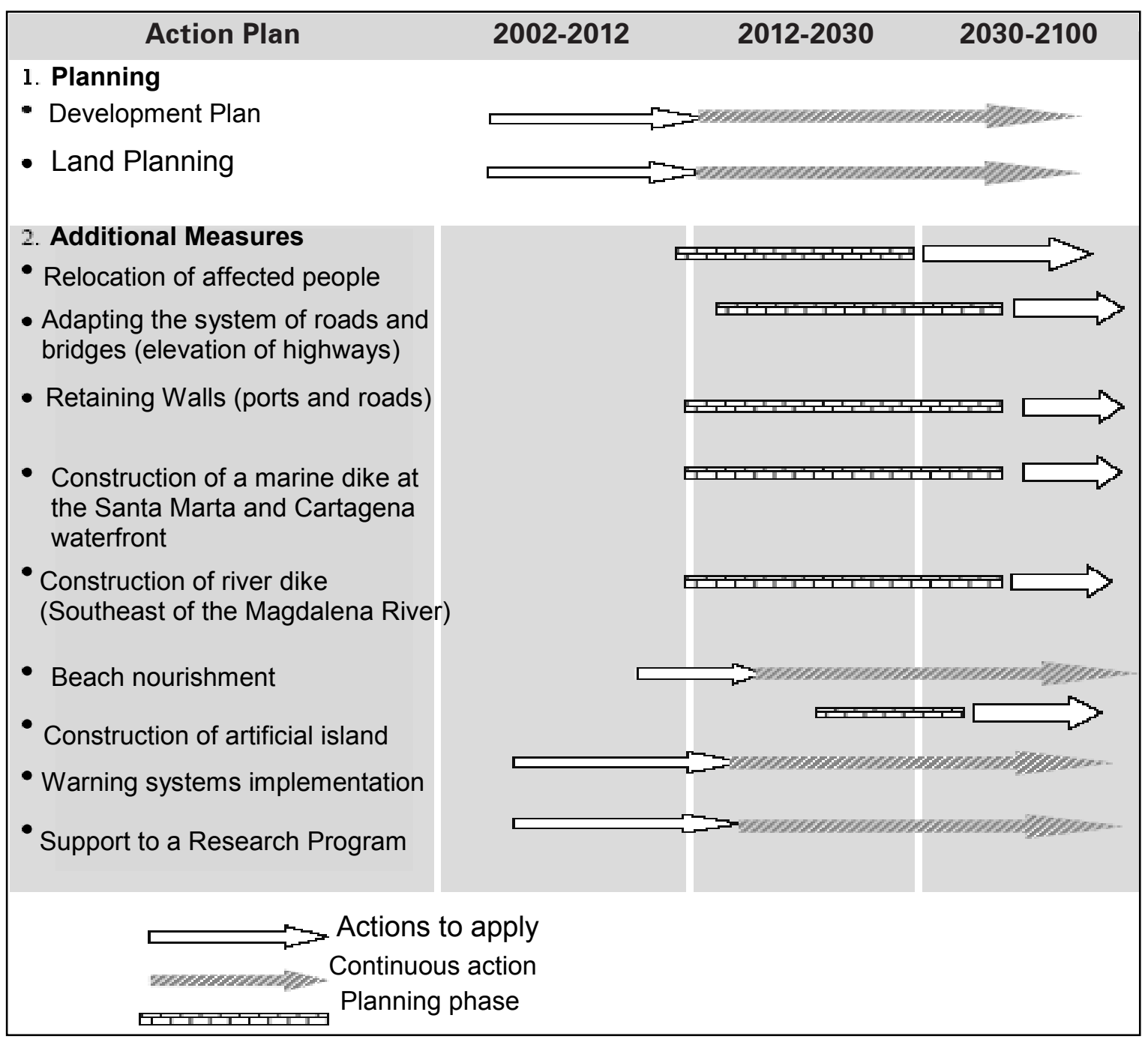

Source: Study NCCSAP: Colombia. INVEMAR (2003)

Besides, according to Gibbs (1984), economists have divided welfare impacts into two main categories: (i) market and (ii) non-market damages. Market damages are the welfare impacts resulting from productivity changes and reflected in changes in prices or quantities of marketed goods. Nonmarket damages include the direct utility loss as a result of less hospitable climate, loss ecosystem services and biodiversity. Gibbs (1984) stated that both the impacts of the SLR and the value of the adaptation measures are large, because market and non-market damages resulting from environmental changes represented revisions in investment in response to the SLR. As a consequence, climate change impacts may influence the decision-making process to reach sustainable development (Magrin et al. 2007), since climate change and SLR bring biophysical and environmental changes that affect human welfare, because of the link between the environment and the socio-economic systems (Pizer and Goulder, 2005).

On the whole, human adaptive responses to climate change are an investment decision (EPA, 1995). These actions protect public goods from 
adverse impacts of climate change and generate benefits (Leary, 1999), but their materialization involves tradeoffs in allocating resources. Furthermore, investment choices are irreversible policies, conditioned by the magnitude of the impacts and the potential of the measures to reduce adverse impacts of the SLR. However, because of the uncertainties about the likelihood of global warming and the time frame over which impacts may become apparent, Titus (1990) suggested that governments only carried out those adaptation measures which significantly reduced the adverse impacts of sea-level rise, but did not risk the investment if the projected effects of global warming failed to materialise.

Therefore, decision makers have a great need for a framework to evaluate the adaptive responses to achieve mitigation, such as the CBA. This analytical tool has the potential to advance the allocation of a provision for environmental impacts in the project cycle and to provide the means of comparison of projects, even when benefits and costs are produced at different time periods (Wattage et al, 2000). Thus, protection is advised only if its benefits are greater than the costs (Ng and Mendelsohn, 2006). Nevertheless, all projects linked with the environment and applying this approach face serious hurdles, since environmental benefits are difficult to quantify due to the numerous nonmarket values attached to the natural resource management and they cannot easily be measured in monetary terms. Consequently, using traditional economic approaches for these non-market goods could be undervalued (Wattage et al, 2000).

In fact, Leary (1999) claimed the necessity for an additional criterion to judge benefit estimation from adaptation measures other than the pure efficiency criterion, because information about the future of climate, climate variability, and the benefits and costs of adapting options have attributes of public goods. Although, several objections have been made regarding the idea of assessing and putting a "price" on non-marketable goods, literature has shown "economic valuation" as an important tool in the process of managing natural resources. Moreover, economic valuation can be useful by providing a way to justify and set priorities for programs, policies or action for protecting or restoring ecosystems and their services.

As a result, there is a strong tendency among scientists to use the framework that integrates CBA and an economic valuation. For instance, $\mathrm{Ng}$ and Mendelsohn's (2006) integrated both methodologies to asses the economic impact of the SLR on non-market lands such as beaches, marshes, mangroves and estuaries in Singapore. They explored two measures of the benefits of protecting natural sites from the damage caused by SLR. Using CVM and Travel Cost approaches, they weighed the benefits of the non-market coastal resources against the cost of protection. The results suggested that it would be cost effective to protect the beaches in every sea-level rise scenario. At the same time, only the CVM analysis suggested that it would be worth for Singapore to protect its marshes and mangroves. The study concludes that in the long run, mangroves and marshes can also survive by migrating inland as the sea rises, but the high level of development in Singapore makes other alternatives such as hard structures more attractive. A similar assessment could help policy makers in Colombia in their decision to protect the coastal areas against SLR.

\section{METHODOLOGY}

Relevant economic approaches are used to measure the welfare changes associated with the protection of the Colombian Caribbean coast from SLR. To estimate the benefits of an adaptation plan, this study uses a CVM to value the market and the non-market benefits. The CVM approach involves asking respondents their willingness to pay (WTP) for the adaptation plan to be implemented. The 
survey was carried out in the three main cities of the Colombian Caribbean Coast: Barranquilla, Cartagena and Santa Marta, which according to INVEMAR (2003) are risky areas due to the SLR. In order to assess the viability of the protection Plan a CBA was carried out over a 100 year period; in which the CVM estimated benefits were weighed against the estimated cost of the protection. This cost was provided by the "Netherlands Climate Change Studies Assistance Programme-NCCSAP: Colombia".

\subsection{Economic valuation}

Non-market valuation techniques are classified into two major groups: On one hand, the direct approach, also called "attitudinal approach", measures values from what people consider and say about their preferences ( $\mathrm{Ng}$ and Mendelsohn, 2006). This technique uses surveys to obtain individual valuation for hypothetical changes in environmental resources. The most used direct method is the CVM, which is considered to be the only methodology simultaneously capable of obtaining "non-use values" and "use values" in the estimation of the welfare changes (Hanemann, 1994; Mitchell and Carson, 1989; Chaudry, Singh and Tewari 2007). On the other hand, the indirect approach or "behavioural technique" analyses the behaviour of the actual markets based on the household decisions to consume commodities connected with non-market goods, so those decisions can reveal its value (( $\mathrm{Ng}$ and Mendelsohn, 2006; Chaudry, Singh and Tewari, 2007). Travel Cost Method, for example, deduces the natural resource values based on the decisions of visitors to travel to the site from different distances ( $\mathrm{Ng}$ and Mendelsohn, 2006).

The CVM uses survey questions to estimate people's preferences for public goods by finding out what they would be willing to pay for specified improvements. "Willingness to Pay" has been defined by Leary (1999) as the sum of money, paid either by an individual or a household, which would have an equivalent effect on the individual's welfare as would the policy. It represents a package of commodities that the individual would be willing to sacrifice or exchange for a different package of commodities that would be made available to the individual by the implementation of the policy. Therefore, it is important to inform the respondents about the valuation situation. The individual should have complete information on the benefits of the good, and they should understand the natural resource present situation and the hypothetical changes in quality or quantity terms (Chaudry, Singh and Tewari, 2007), to ensure the uniformity of the conceptualization (Mitchell and Carson, 1989). This information is given by the survey as the creation of the hypothetical scenario which specifies a variety of states of the good to be valued and the conditions of its provision.

\subsection{Survey data}

\subsubsection{Sample size}

A contingent valuation study requires large sample sizes because of the large variance in the WTP responses. To obtain an acceptable degree of precision in sample statistics, for the sample needed it was decided to use a coefficient of variation of 2.0; a percentage distribution between the true WTP and the estimated WTP of 0.15 and $90 \%(1-,=0.1)$ confidence level with the $t$ value of 1.69. These give a sample size of 508 (Mitchell and Carson, 1989). This sample size was divided into the three main cities of the Colombian Caribbean Coast: Barranquilla, Cartagena and Santa Marta (168 each).

In order to obtain reliable results and to ensure the maximum positive response rate, the survey was conducted by face-to-face interviews, following Chaudry, Singh and Tewari (2007) suggestions. The survey was conducted over a period of one week in November of 2007 with the help of the students 
from the School of Economics of the "Universidad del Magdalena-Colombia".

\subsection{Questionnaire}

The questionnaire used in this survey consists of 17 questions and took approximately from 15 to 20 minutes to be completed. The questionnaire was divided into five parts:

- Scenario Description: the scenario for the hypothetical market was created based on the study NCCSAP: Colombia. In the questionnaire, respondents were presented with possible consequences of the SLR in the Caribbean region. The Adaptation plan for protecting the coast from the SLR with the additional measures and their cost were also presented.

- Perception problem: Questions 1 to 5 inquired about any direct effect of the SLR on respondents, which may influence their WTP. The direct effects of the SLR included floods, distance between the respondents' home and coast, and the number of years the respondent had lived in the location. Question 6 was an attitudinal question to understand the opinion of the people about climate change consequences. In question 7 respondents were asked to evaluate the proposed additional measures according to their degree of urgency.

- The WTP Question: The scenario or introduction to the WTP question (question 8) was designed based on Whittington's (1998) suggestion about constructing joint public-private CVM scenarios in developing countries to evaluate infrastructure projects. Whittington noted that a household in a developing country would vote in favour of a project and agree to pay some share of the capital costs if it were a collective decision. Therefore, the scenario for the WTP question needed to present information about the terms and conditions of both parts of the "deal". In this study this "deal" was created between the government, non-governmental organizations (NGOs) and the people. In this scenario, the government was in charge of carrying out the developmental plan for the cities and the NGO with the support of the people dealt with the additional measures. Moreover, to minimize non-responses, the chosen payment vehicle was the bill of one of the utilities instead of a direct tax. The WTP question was as follows: "How much would you be Willing To Pay per month, in one of your utility bills, to carry out the additional measures?"

- To obtain the WTP, values were created out of a combination of the bidding game which was an iterative dichotomous choice format (yes/no responses) and open-ended questions which asked for the maximum WTP. The initial bid was chosen by the "Delphi Method", which incorporated experts' judgment. The pool of experts included scientists and professors from the School of Economics of the Universidad del Magdalena-Colombia.

- Socio-economic information: Questions 10 to 16 sought data on respondents' socio-economic status such as occupation, education and household size. Question 17 asks about the level of income. Respondents were requested to select from a group of income bands, following again Chaudry, Singh and Tewari (2007) suggestions: in developing countries people are often not willing or able to precisely state their income during surveys.

\subsection{Models and variables}

To analyze the data collected from the survey, Stata8 and SPSS were used. The WTP question generated two dependent variables: levels of WTP (duowtp) which has eight ordered categories given by the iterative dichotomous choice format (yes/no responses) and the Maximum WTP (maxwtp) given by open-ended question. The variables included in the regression models were based on the reviewed studies presented in Table 2 plus the outcome of the cross-tabulation analysis (Table 6) and the correlation matrix. 
The model to be estimated is given as:

$$
\mathrm{WTP}=\mathrm{f}(\mathrm{V})
$$

Where:

$$
\begin{aligned}
& \text { WTP }=\text { Willingness to Pay } \\
& \text { V = Vector of explanatory variables (see } \\
& \text { column } 4 \text { of Table } 2 \text { ) }
\end{aligned}
$$

\subsubsection{Estimation of the mean maximum willingness to pay (WTP)}

Before the estimation of the regressions it is important to briefly discuss the descriptive statistics and trends (histograms) for all the variables. This is done to check the accuracy of the data. Specifically the trend in the dependent variable, maxwtp, needs to be analysed (see Figure 1A) to exclude from the estimation unreasonably high bids "outliers" which can occur due to a strategic behavior or "yea-saying" and also exclude "protest votes" when the respondents are not WTP because they are not valuing the good as an objection to the payment vehicle or to the hypothetical scenario. The outliers were identified as WTP amounts greater than $10 \%$ of the income, while the protest vote were identified by the respondents' reasons for not WTP. These are shown in Table 3.

It is evident from the responses that the main reason for the non willingness to pay is not the low income of the people. This is what Chaudry, Singh and Tewari (2007), called the "Government Dependence", which is related to the majority of middle and upper middle level of income respondents, who argue that it is the duty of the government to invest in environmental improvement. As a result, respondents who answered that "the government should pay for it", "the utilities bills and taxes are very expensive" and "a believe in the corruption of government" were identified as reasons for being protesters. Both outliers and protest votes were

\begin{tabular}{|c|c|c|c|}
\hline $\begin{array}{l}\mathrm{Ng} \text { W. and Mendelsohn (2006) } \\
\text { "The Economic Impact of Sea- } \\
\text { level Rise on Nonmarket Lands } \\
\text { in Singapore" }\end{array}$ & $\begin{array}{l}\text { Wattage et al. (2000) "Inte- } \\
\text { grating environmental impact, } \\
\text { contingent valuation and cost- } \\
\text { benefit analysis: empirical evi- } \\
\text { dence for alternative perspective" }\end{array}$ & $\begin{array}{l}\text { Chaudry, Singh and Tewari } \\
\text { (2007) "Non-market econo- } \\
\text { mic valuation in developing } \\
\text { countries: Role of participant } \\
\text { observation method in CVM } \\
\text { analysis" }\end{array}$ & $\begin{array}{l}\text { This Study } \\
\text { WTP }=f(\mathrm{~V}) \\
\text { V=variables }\end{array}$ \\
\hline $\begin{array}{l}\text { - Age } \\
\text { - Gender } \\
\text { - Number of children } \\
\text { - Education level } \\
\text { - family size } \\
\text { - income level }\end{array}$ & $\begin{array}{l}\text { - Gross Income } \\
\text { - Education } \\
\text { - Age } \\
\text { - household size } \\
\text { - Gender } \\
\text { - present water quality } \\
\text { - Expected level of water } \\
\text { - quality } \\
\text { - Member of an environ- } \\
\text { - } \text { Distantal organization }\end{array}$ & $\begin{array}{l}\text { - Occupation } \\
\text { - Net house monthly inco- } \\
\text { - } \text { he } \\
\text { - Educehold size } \\
\text { tion } \\
\text { - Age } \\
\text { - Environmental aware- } \\
\text { ness }\end{array}$ & $\begin{array}{l}\text { - Income } \\
\text { - Occupation } \\
\text { - Education level } \\
\text { - Number of children } \\
\text { - Household size } \\
\text { - Marital status } \\
\text { - Gender } \\
\text { - Age } \\
\text { - Distance } \\
\text { - Years living in that loca- } \\
\text { - tion } \\
\text { - Action Plan measures } \\
\text { - Fity } \\
\text { - Environmental aware- } \\
\text { ness: Climate change }\end{array}$ \\
\hline
\end{tabular}
removed from the dataset leaving a total of 434 respondents for the estimation (Figure 1B).

Table 2. Variables included in the WTP model

Source: Ng W. and Mendelsohn (2006), Wattage et al. (2000), Chaudry, Singh and Tewari (2007) 
Table 3. Reasons given for not WTP

\begin{tabular}{|l|c|c|}
\hline \multicolumn{1}{|c|}{ Reasons } & Times & Percent \\
\hline \multicolumn{1}{|c|}{ Can not afford it } & 3 & $3.90 \%$ \\
\hline Unemployed & 3 & $3.90 \%$ \\
\hline The damages are not notorious and it is not necessary & 3 & $3.90 \%$ \\
\hline Agreement between the government, NGO, international organization & 3 & $3.90 \%$ \\
\hline The government should pay for it & 45 & $58.44 \%$ \\
\hline The utilities bills and taxes are very expensive & 8 & $10.39 \%$ \\
\hline A believe in the corruption of government & 12 & $15.58 \%$ \\
\hline Total & 77 & $100 \%$ \\
\hline
\end{tabular}

Source: made by the author

Figure 1. A: Histogram and descriptive statistics of the Initial maximum WTP. B: Histogram and descriptive statistics of the final maximum WTP (After removing outliers and protest vote)

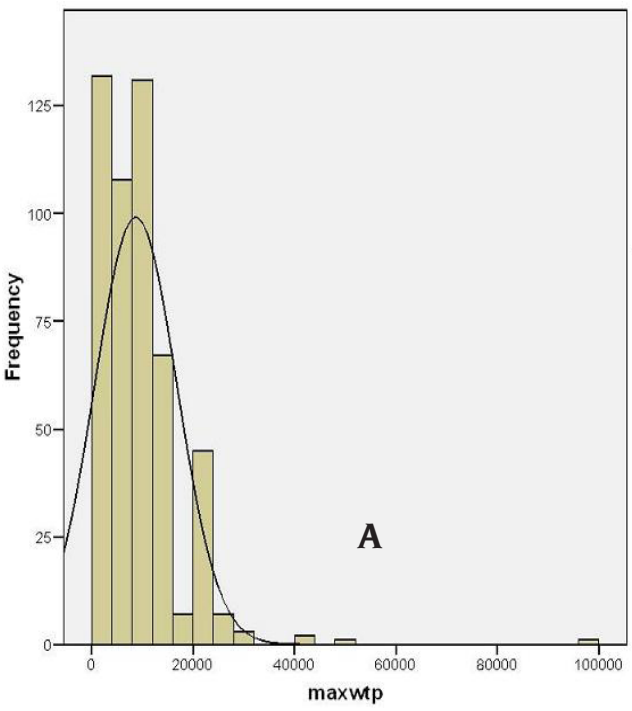

\begin{tabular}{|ll|r|r|}
\hline & \multicolumn{1}{|c|}{ Statistic } & Std. Error \\
\hline maxwtp & Mean & 8733,73 & 361,384 \\
& $95 \%$ Confidence $\quad$ Lower Bound & 8023,72 & \\
& Interval for Mean $\quad$ Upper Bound & 9443,74 & \\
& & 8127,87 & \\
5\% Trimmed Mean & 8000,00 & \\
Median & 65821484, & \\
Variance & 269 & \\
Std. Deviation & 8113,044 & \\
Minimum & 100000 & \\
Maximum & 100000 & \\
Range & 9000 & \\
Interquartile Range & 3,564 &, 109 \\
Skewness & 32,562 &, 217 \\
Kurtosis & & \\
\hline
\end{tabular}

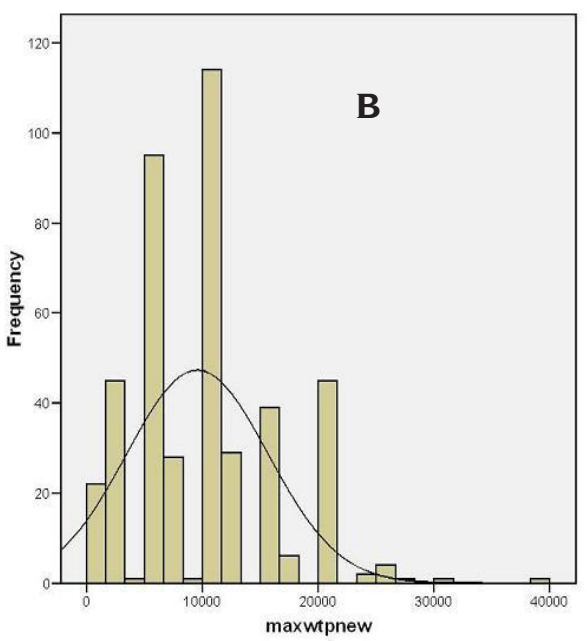

Mean= 9577.88

Std. Dev. $=6100.393$

$\mathrm{N}=434$

Std. Dev.= 8113.044

$\mathrm{N}=504$

Source: made by the author

\begin{tabular}{|c|c|c|c|c|}
\hline \multirow{14}{*}{\begin{tabular}{|l|} 
\\
maxwtpnew
\end{tabular}} & & & Statistic & Std. Error \\
\hline & \multicolumn{2}{|l|}{ Mean } & 9577,88 & 292,828 \\
\hline & \multirow{2}{*}{$\begin{array}{l}95 \% \text { Confidence } \\
\text { Interval for Mean }\end{array}$} & \multirow{12}{*}{$\begin{array}{l}\text { Lower Bound } \\
\text { Upper Bound }\end{array}$} & 9002,34 & \\
\hline & & & 10153,42 & \\
\hline & $5 \%$ Trimmed Mea & & 9337,17 & \\
\hline & Median & & 10000,00 & \\
\hline & Variance & & 37214798 , & \\
\hline & Std. Deviation & & 6100,393 & \\
\hline & Minimum & & 0 & \\
\hline & Maximum & & 40000 & \\
\hline & Range & & 40000 & \\
\hline & Interquartile Rang & & 7125 & \\
\hline & Skewness & & .824 & .117 \\
\hline & Kurtosis & & 1.014 & .234 \\
\hline
\end{tabular}


Table 4. Tabulation of the variables introduced in the data set

\begin{tabular}{|c|c|c|c|}
\hline \multicolumn{4}{|c|}{ Tabulation } \\
\hline \multicolumn{4}{|c|}{ Variables } \\
\hline \multicolumn{2}{|l|}{ maxwtp } & \multicolumn{2}{|l|}{ Marital status } \\
\hline wtp $=0$ & $15.28 \%$ & Single & $42.46 \%$ \\
\hline $1<$ wtp $<2000$ & $1.98 \%$ & Married & $41.27 \%$ \\
\hline $2000<=$ wtp $<5000$ & $9.13 \%$ & Cohabiting & $9.92 \%$ \\
\hline $5000<=$ duowtp $<10000$ & $24.60 \%$ & Divorced & $6.35 \%$ \\
\hline $10000<=$ wtp $<15000$ & $28.37 \%$ & \multicolumn{2}{|l|}{ Occupation } \\
\hline $15000<=$ wtp $<20000$ & $8.93 \%$ & Students and part time employed & $16.27 \%$ \\
\hline wtp $=20000$ & $8.93 \%$ & Employed & $44.05 \%$ \\
\hline wtp $>20000$ & $2.78 \%$ & Self employed & $25.00 \%$ \\
\hline \multicolumn{2}{|l|}{ Income } & Retired & $4.56 \%$ \\
\hline Income $=<500000$ & $45.44 \%$ & Housewife and others & $10.12 \%$ \\
\hline Income>500000-1mill & $38.49 \%$ & \multicolumn{2}{|l|}{ City } \\
\hline Income $=1$ mill -2 mill & $10.91 \%$ & Cartagena & $33.33 \%$ \\
\hline$>2$ mill & $5.16 \%$ & Santa Marta & $33.33 \%$ \\
\hline \multicolumn{2}{|l|}{ Education } & Barranquilla & $33.33 \%$ \\
\hline Primary school & $9.13 \%$ & \multicolumn{2}{|l|}{ Distance } \\
\hline Secondary & $38.69 \%$ & Distance $<=15 \mathrm{~min}$ & $32.14 \%$ \\
\hline Technical training & $23.61 \%$ & $15 \mathrm{~min}<$ distance $<=30 \mathrm{~min}$ & $22.42 \%$ \\
\hline Bachelor degree & $23.41 \%$ & $30 \mathrm{~min}<$ distance $<=60 \mathrm{~min}$ & $35.52 \%$ \\
\hline Master degree & $3.97 \%$ & distance $>60$ & $9.92 \%$ \\
\hline PhD & $1.19 \%$ & \multicolumn{2}{|l|}{ Age } \\
\hline \multicolumn{2}{|l|}{ Opinion: climate change } & age $<=20$ & $12.30 \%$ \\
\hline Don't know & $4.56 \%$ & $20<$ age $<=30$ & $37.10 \%$ \\
\hline Not Noticeable & $2.98 \%$ & $30<$ age $<=40$ & $23.41 \%$ \\
\hline Serious & $38.4 \%$ & age $>40$ & $27.18 \%$ \\
\hline Very serious & $53.97 \%$ & \multicolumn{2}{|l|}{ Children } \\
\hline Respondents' who had houses flooded & $25.99 \%$ & children $=0$ & $33.73 \%$ \\
\hline $\begin{array}{l}\text { Respondents' who own the property } \\
\text { where they live }\end{array}$ & $50 \%$ & $0<$ children $<=3$ & $53.17 \%$ \\
\hline \multicolumn{2}{|l|}{ Gender } & children $>3$ & $13.10 \%$ \\
\hline Female & $54.37 \%$ & \multicolumn{2}{|l|}{ Household size } \\
\hline \multirow{2}{*}{ Male } & \multirow{2}{*}{$45.63 \%$} & Household size $<=5$ & $64.29 \%$ \\
\hline & & household $>5$ & $35.71 \%$ \\
\hline
\end{tabular}

Source: made by the author 
Finally, three types of models were estimated: An ordinary Least Square (OLS), Ordered probit (oprobit) and Ordered Logit (ologit). The OLS was used to estimate the factors influencing the amount of money that the respondents would be willing to pay, while the Oprobit and Ologit models determined factors influencing the respondents' probability of willing to pay the WTP ordered categories. Oprobit and Ologit are ordered multinomial models, where the dependent variable is an ordered response, and the values assigned to each outcome are not arbitrary but have highest and lowest rating such as the levels of WTP (Wooldridge, 2002).

\section{RESULTS}

\subsection{Descriptive statistics of the variables}

Summary statistics of relevant variables are presented in Table 4. All estimates in this study were expressed in terms of 2007 United States dollars (USD). The results indicate that $15.28 \%$ of the respondents are not WTP and from those who are WTP most (54.97\%) would be willing to pay between 2,41 USD to 7,22 USD per month. Additionally, although the sample was random, $83.93 \%$ of the respondents have the two lowest levels of income (less that 240,58 USD (45.43\%) and between 240,58 USD to less than 481,15 USD (38.49\%) ). This is not surprising since the legal minimum wage in Colombia for 2007 is 208,68 USD per month, and most people (45.43\%) in the surveyed areas fall in the low income group.

Figure 2. Respondents opinion on consequences of SLR and climate change.

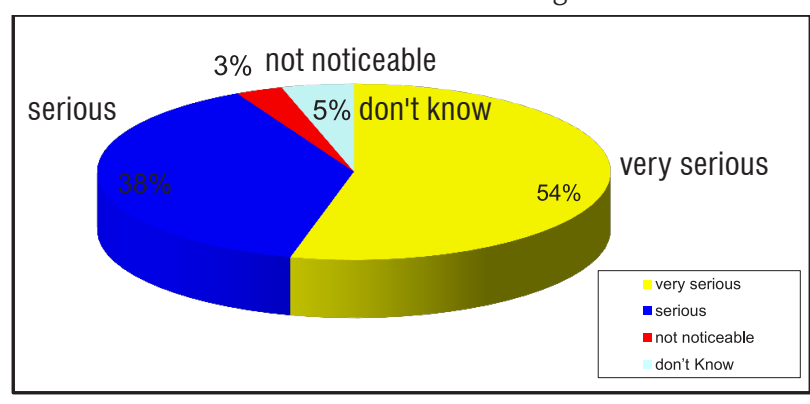

Source: made by the author
Results also show a high degree of climate change and SLR awareness among the respondents. For instance, $53.97 \%$ of the respondents observe that the consequences of SLR and climate change in Colombia are "very serious" while 38.49\% think that they are "serious" (see figure 2) This high degree of awareness relate closely with the degree of urgency respondents attached to "Additional Measures" that need to be taken in response to SLR. Approximately $70 \%$ of respondents observed that almost all the additional measure should be carried out immediately (see Table 5).

Table 5. Degree of urgency of additional measures

\begin{tabular}{|c|c|c|c|}
\hline Additional Measures & $\begin{array}{l}\text { Immedia- } \\
\text { tely }\end{array}$ & $\begin{array}{c}\text { In } \\
\text { between }\end{array}$ & $\begin{array}{l}\text { Even- } \\
\text { tually }\end{array}$ \\
\hline $\begin{array}{l}\text { Relocation of affected } \\
\text { people }\end{array}$ & $83.33 \%$ & $7.539 \%$ & $9.12 \%$ \\
\hline $\begin{array}{l}\text { Adapting the system of } \\
\text { roads and bridges }\end{array}$ & $70.63 \%$ & $13.69 \%$ & $15.67 \%$ \\
\hline $\begin{array}{l}\text { Retaining Walls (ports } \\
\text { and roads) }\end{array}$ & $70.83 \%$ & $14.28 \%$ & $14.88 \%$ \\
\hline $\begin{array}{l}\text { Construction of a ma- } \\
\text { rine dike at the Santa } \\
\text { Marta and Cartagena } \\
\text { seafront }\end{array}$ & $64.48 \%$ & $13.29 \%$ & $22.22 \%$ \\
\hline $\begin{array}{l}\text { Construction of river } \\
\text { dike (Southeast of the } \\
\text { Magdalena River) }\end{array}$ & $67.65 \%$ & $12.89 \%$ & $19.44 \%$ \\
\hline Beach nourishment & $55.95 \%$ & $16.07 \%$ & $27.97 \%$ \\
\hline $\begin{array}{l}\text { Construction of Artifi- } \\
\text { cial reefs }\end{array}$ & $49.60 \%$ & $16.26 \%$ & $34.12 \%$ \\
\hline $\begin{array}{l}\text { Construction of artifi- } \\
\text { cial island }\end{array}$ & $44.04 \%$ & $12.89 \%$ & $43.05 \%$ \\
\hline $\begin{array}{l}\text { Warning systems im- } \\
\text { plementation }\end{array}$ & $90.67 \%$ & $2.97 \%$ & $06.34 \%$ \\
\hline $\begin{array}{l}\text { Support to a Research } \\
\text { Program }\end{array}$ & $80.95 \%$ & $06.54 \%$ & $12.5 \%$ \\
\hline
\end{tabular}

Source: made by the author

A cross tabulation analysis was undertaken between relevant variables and the WTP levels to assess the level of significance among difference 
groups and their WTP for carrying out the additional measures. The chi-square estimates for most of the relevant variables were significant which implied that the influence of each of the groupings on the WTP is significantly different (Table 6). For example, the significance of the chi-square for the WTP-income and WTP-education relationship shows that different levels of both income and education variables have different relationships with WTP. For income, the higher proportion of high income group in the high WTP band (15.44\%), and the highest percentage of the respondents not WTP who fall in the two lowest income groups (84\%) indicate a possible positive relationship between income and WTP. This can be directly compared with the education variable in which $79.22 \%$ of the respondents that are not WTP have the three lowest levels of education and $78.57 \%$ of the respondents that have the highest level of WTP also have the three highest levels of education.

A higher proportion of men are WTP (63.64\% of the respondents that are not WTP are women), while $55 \%$ of the respondents that are WTP more than 4,81 USD are men. $61.04 \%$ of the respondents that are not WTP are not married while $53.68 \%$ of the respondents that are WTP the highest level of WTP are married. Moreover, respondents from Santa Marta are likely to be willing to pay the lowest levels amounts since $62.34 \%$ of the respondents that are not WTP are from Santa Marta and the majority of the people that are WTP the highest levels amounts are from Barranquilla and Cartagena.

Table 6. Cross Tabulation between the WTP and all the variables used in the model

\begin{tabular}{|c|c|c|c|c|}
\hline \multicolumn{5}{|c|}{ maxwtp } \\
\hline Variables & $\max w t p=0$ & $0<\operatorname{maxwt} p<=4,81$ USD & maxwtp $>4,81$ USD & Chi-square (Pr) \\
\hline maxwtp & $15.28 \%$ & $57.74 \%$ & $26.98 \%$ & \\
\hline Income & & & & 0.000 \\
\hline Income $=<500000$ & $54.55 \%$ & $50.17 \%$ & $30.15 \%$ & \\
\hline Income $>500000-1 \mathrm{mill}$ & $29.87 \%$ & $41.24 \%$ & $37.50 \%$ & \\
\hline Income $=1 \mathrm{mill}-2 \mathrm{mill}$ & $12.99 \%$ & $7.56 \%$ & $16.91 \%$ & \\
\hline$>2 \mathrm{mill}$ & $2.60 \%$ & $1.03 \%$ & $15.44 \%$ & \\
\hline Education & & & & 0.000 \\
\hline Primary school & $9.09 \%$ & $11 \%$ & $5.15 \%$ & \\
\hline Secondary & $41.56 \%$ & $43.99 \%$ & $25.74 \%$ & \\
\hline Technical training & $28.57 \%$ & $21.65 \%$ & $25 \%$ & \\
\hline Bachelor degree & $15.58 \%$ & $20.96 \%$ & $33.09 \%$ & \\
\hline Master degree & $3.90 \%$ & $2.41 \%$ & $7.35 \%$ & \\
\hline PhD & $1.30 \%$ & $0 \%$ & $3.68 \%$ & \\
\hline Opinion: climate change & & & & 0.193 \\
\hline Don't know & $6.49 \%$ & $4.81 \%$ & $2.94 \%$ & \\
\hline Not Noticeable & $5.19 \%$ & $3.09 \%$ & $1.47 \%$ & \\
\hline Serious & $38.96 \%$ & $41.24 \%$ & $32.35 \%$ & \\
\hline Very serious & $49.35 \%$ & $50.86 \%$ & $63.24 \%$ & \\
\hline Respondents' who had houses flooded & $29.87 \%$ & $28.18 \%$ & $19.12 \%$ & 0.097 \\
\hline Own the property & $50.65 \%$ & $47.08 \%$ & $55.88 \%$ & 0.236 \\
\hline
\end{tabular}




\begin{tabular}{|c|c|c|c|c|}
\hline \multicolumn{5}{|c|}{ maxwtp } \\
\hline Variables & maxwtp $=0$ & $0<\operatorname{maxwt} p<=4,81$ USD & maxwtp $>4,81$ USD & Chi-square (Pr) \\
\hline Gender & & & & 0.017 \\
\hline Female & $63.64 \%$ & $56.36 \%$ & $44.85 \%$ & \\
\hline Male & $36.36 \%$ & $43.64 \%$ & $55.15 \%$ & \\
\hline Marital status & & & & 0.020 \\
\hline Single & $38.96 \%$ & $48.11 \%$ & $32.35 \%$ & \\
\hline Married & $38.96 \%$ & $36.08 \%$ & $53.68 \%$ & \\
\hline Cohabiting & $12.99 \%$ & $9.97 \%$ & $8.09 \%$ & \\
\hline Divorced & $9.09 \%$ & $5.84 \%$ & $5.88 \%$ & \\
\hline Occupation & & & & 0.001 \\
\hline Students and part time employed & $11.69 \%$ & $17.87 \%$ & $15.44 \%$ & \\
\hline Employed & $61.04 \%$ & $37.46 \%$ & $48.53 \%$ & \\
\hline Self employed & $15.28 \%$ & $30.58 \%$ & $19.85 \%$ & \\
\hline Retired & $5.19 \%$ & $2.75 \%$ & $8.09 \%$ & \\
\hline Housewife and others & $9.09 \%$ & $11.34 \%$ & $8.09 \%$ & \\
\hline City & & & & 0.000 \\
\hline Cartagena & $16.88 \%$ & $34.71 \%$ & $39.71 \%$ & \\
\hline Santa Marta & $62.34 \%$ & $30.93 \%$ & $22.06 \%$ & \\
\hline Barranquilla & $20.78 \%$ & $34.36 \%$ & $38.24 \%$ & \\
\hline Distance & & & & 0.138 \\
\hline Distance $<=15 \mathrm{~min}$ & $44.16 \%$ & $30.93 \%$ & $27.94 \%$ & \\
\hline $15 \mathrm{~min}<$ distance $<=30 \mathrm{~min}$ & $23.38 \%$ & $21.31 \%$ & $24.26 \%$ & \\
\hline $30 \mathrm{~min}<$ distance $<=60 \mathrm{~min}$ & $25.97 \%$ & $36.08 \%$ & $39.71 \%$ & \\
\hline distance $>60$ & $6.49 \%$ & $11.68 \%$ & $8.09 \%$ & \\
\hline Age & & & & 0.047 \\
\hline age $<=20$ & $11.69 \%$ & $15.46 \%$ & $5.88 \%$ & \\
\hline $20<$ age $<=30$ & $36.36 \%$ & $36.43 \%$ & $38.97 \%$ & \\
\hline $30<$ age $<=40$ & $16.88 \%$ & $24.74 \%$ & $24.26 \%$ & \\
\hline age $>40$ & $35.06 \%$ & $23.37 \%$ & $30.88 \%$ & \\
\hline Children & & & & 0.301 \\
\hline children $=0$ & $27.27 \%$ & $36.77 \%$ & $30.88 \%$ & \\
\hline $0<$ children $<=3$ & $59.74 \%$ & $49.14 \%$ & $58.09 \%$ & \\
\hline children $>3$ & $12.99 \%$ & $14.09 \%$ & $11.03 \%$ & \\
\hline Household size & & & & 0.493 \\
\hline Household size $<=5$ & $58.44 \%$ & $64.95 \%$ & $66.18 \%$ & \\
\hline household $>5$ & $41.56 \%$ & $35.05 \%$ & $33.82 \%$ & \\
\hline household $>5$ & $41.56 \%$ & $35.05 \%$ & $33.82 \%$ & \\
\hline
\end{tabular}

Source: made by the author 


\subsection{Estimated regression models}

Table 7. A. Regression with the category variables

B. Regression with the subcategories of the significant variables

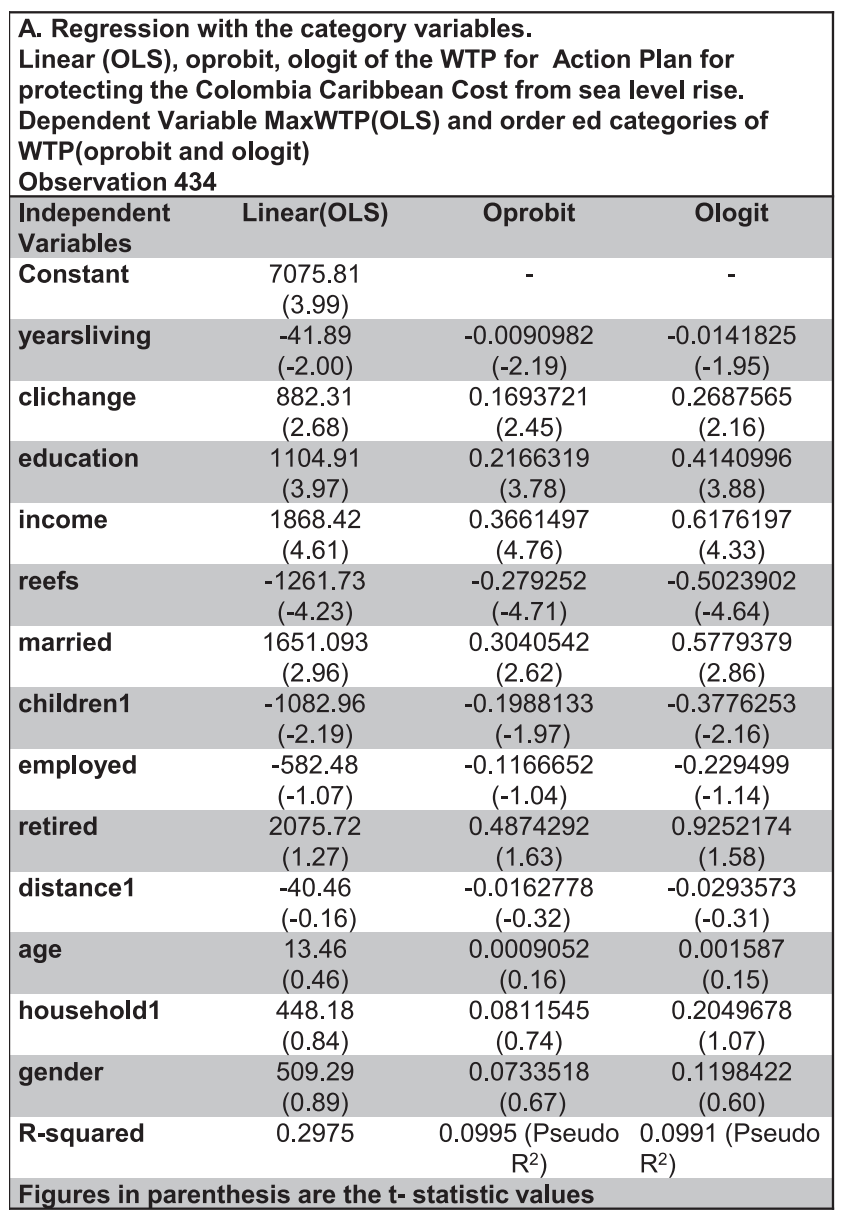

Source: made by the author

Two main estimations for the three models were run. Regression A in Table 7, includes variables indicated by studies presented in Table 2. The results show that, although, some of the variables were not significant (gender, household size, distance from home to coast, occupation such as retired and employed) the signs can be closely compared with Ng and Mendelsohn (2006) findings. The signs are important because they reflect the direction of the relationship between the variables and the WTP for carrying the additional measures. For instance, Ng and Mendelsohn (2006)

\begin{tabular}{|c|c|c|c|}
\hline \multicolumn{4}{|c|}{$\begin{array}{l}\text { B. Regression with the subcategories variables. } \\
\text { Linear(OLS), oprobit, ologit of the WTP for Action Plan for } \\
\text { protecting the Colombia Caribbean Cost from sea level rise. } \\
\text { Dependent Variable MaxWTP(OLS) and order edcategories of } \\
\text { WTP(oprobit and ologit) } \\
\text { Observation } 434\end{array}$} \\
\hline $\begin{array}{l}\text { Independent } \\
\text { Variables }\end{array}$ & Linear(OLS) & Oprobit & Ologit \\
\hline Constant & $\begin{array}{c}7923.402 \\
(9.79)\end{array}$ & - & - \\
\hline yearsliving & $\begin{array}{c}-30.26435 \\
(-1.57)\end{array}$ & $\begin{array}{c}-0.0064453 \\
(-1.60)\end{array}$ & $\begin{array}{c}-0.0110632 \\
(-1.58)\end{array}$ \\
\hline clichange_2 & $\begin{array}{c}-3739.836 \\
(-3.69)\end{array}$ & $\begin{array}{c}-0.9424834 \\
(-3.07)\end{array}$ & $\begin{array}{c}-0.54933 \\
(-2.90)\end{array}$ \\
\hline clichange_4 & $\begin{array}{c}1316.794 \\
(2.54)\end{array}$ & $\begin{array}{c}0.2348657 \\
(2.23)\end{array}$ & $\begin{array}{c}0.379905 \\
(2.06)\end{array}$ \\
\hline education_4 & $\begin{array}{c}920.3498 \\
(1.44)\end{array}$ & $\begin{array}{c}0.199425 \\
(1.59)\end{array}$ & $\begin{array}{c}0.3707742 \\
(1.70)\end{array}$ \\
\hline education_6 & $\begin{array}{c}5027.74 \\
(1.79)\end{array}$ & $\begin{array}{c}1.329838 \\
(2.26)\end{array}$ & $\begin{array}{c}2.438935 \\
(2.16)\end{array}$ \\
\hline income2_2 & $\begin{array}{c}1146.786 \\
(2.17)\end{array}$ & $\begin{array}{c}0.3010741 \\
(2.67)\end{array}$ & $\begin{array}{c}0.4474699 \\
(2.28)\end{array}$ \\
\hline income2_3 & $\begin{array}{c}3096.445 \\
(3.22)\end{array}$ & $\begin{array}{c}0.6825751 \\
(3.65)\end{array}$ & $\begin{array}{c}1.083118 \\
(3.32)\end{array}$ \\
\hline income2_4 & $\begin{array}{c}10347.24 \\
(5.71)\end{array}$ & $\begin{array}{c}1.94938 \\
(6.79)\end{array}$ & $\begin{array}{c}3.366933 \\
(5.89)\end{array}$ \\
\hline reefs_1 & $\begin{array}{c}2205.742 \\
(4.28)\end{array}$ & $\begin{array}{c}0.4843232 \\
(4.65)\end{array}$ & $\begin{array}{c}0.8758789 \\
(4.74)\end{array}$ \\
\hline Married & $\begin{array}{c}1377.225 \\
(2.54)\end{array}$ & $\begin{array}{c}0.2516672 \\
(2.12)\end{array}$ & $\begin{array}{c}0.4623451 \\
(2.27)\end{array}$ \\
\hline Children1 & $\begin{array}{c}-1007.04 \\
(-2.49)\end{array}$ & $\begin{array}{c}-0.198776 \\
(-2.22)\end{array}$ & $\begin{array}{c}-0.3522406 \\
(-2.28)\end{array}$ \\
\hline R-squared & 0.3182 & $\begin{array}{c}0.1058 \text { (Pseudo } \\
R^{2} \text { ) }\end{array}$ & $\begin{array}{c}0.1033 \text { (Pseudo } \\
R^{2} \text { ) }\end{array}$ \\
\hline
\end{tabular}

results and Regression A, suggest that respondents with children are less likely to be willing to pay for protection of the coast but large families and married respondents are more likely to be willing. Also, respondents with higher incomes were willing to pay more for protection of the coast. $\mathrm{Ng}$ and Mendelsohn (2006) results show that men were willing to pay more, as we find in the cross tabulation analysis; but Regression A suggests the opposite women are willing to pay more. This may be the result of removing the outliers and the protest vote. Additionally, Regression A shows an 
unexpected result. Respondents who have been living less years in that location are willing to pay more for carrying out the additional measures.

In relation to occupation and age the sign shows that older and retired respondents were willing to pay more for carrying out the additional measures. In fact, in the cross-tabulation analysis between WTP and the occupation subcategories, the chi-square is significant for employed and retired. However, the correlation matrix shows that they are also highly correlated with income as a result both variables were not significant in Regression A.

In Regression $B$, the non-significant variables were removed and the subcategories of the significant variables were included in the esti- mation of the models. The interpretation of the estimated coefficients for the oprobit and ologit models in the Regression B is as follows: the higher the value of the subcategory coefficient, the higher the probability of the WTP for this subcategory in the specified main group.

For example, if the oprobit model is fitted for a respondent who has been living in that location for 40 years, is married, does not have children, has a bachelor degree and think that the consequences of SLR and climate change in Colombia are "very serious" and if his level of income is changed; it can be seen in Figure 3A how the probability to be willing to pay a higher level changes. This Figure shows that if the respondent has an income $2(240,58$ 481,15 USD) the most probable level that he would

Figure 3. Change in the probability to pay WTP levels when a respondent change his level of income or education or his opinion about the consequences of climate change
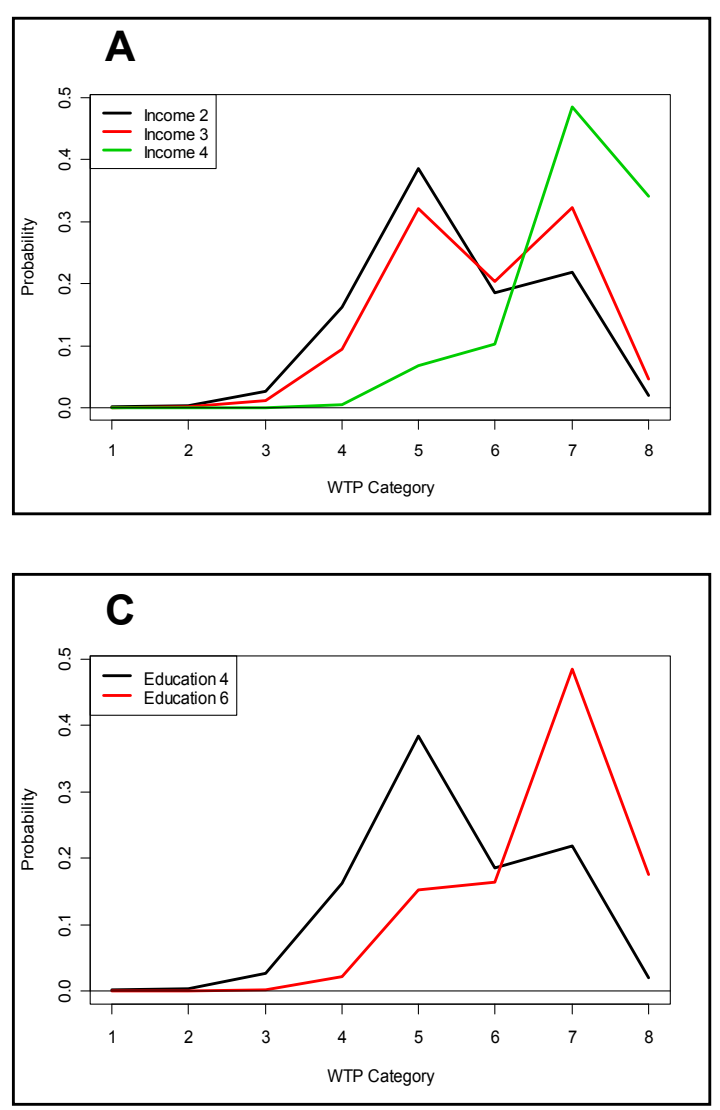

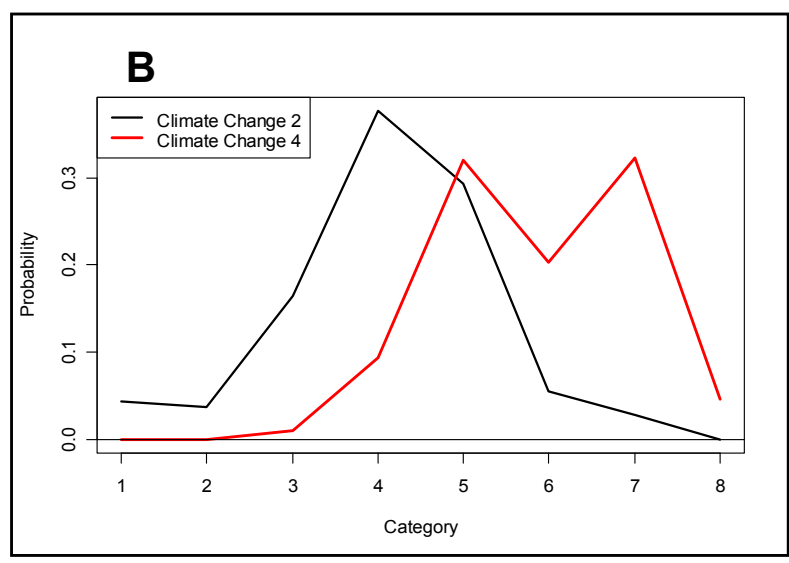

Source: made by the author 
be willing to pay is level 5 ( 4,81 -7,22 USD) but if he has an income 3 (481,15 USD-962,30 USD) there are two most probable levels that he would be willing to pay level 5 and level 7( 9,62 USD). These results may be explained by the influence of the initial bid in the WTP question which was 4,81 USD. However, this influence is very small when the respondent has a high income and it is very probable that he would be in the higher levels of WTP.

Figure 3B shows the changes of the probably to be willing to pay when the same respondent change his education from bachelor degree (education 4) to $\mathrm{PhD}$ (education 6) and figure $1 \mathrm{C}$ when he changes his opinion about the SLR and climate change consequences in Colombia from "not noticeable" (climate change 2) to "very serious" (climate change 4) the results from Figure $3 \mathrm{C}$ and the clichange_2 coefficient in Regression B suggest that respondents who think that the consequences of SLR and climate change in Colombia are "not noticeable" are not willing to pay the highest levels of WTP.

\subsection{Prediction}

Finally, the oprobit model was fitted for all the respondents in order to compare the values of the predicted WTP with the observed WTP. Table 8 shows the comparative matrix between the oprobit predicted and the observed Values of WTP. Both observed and predicted values show that the majority of the respondents were willing to pay from 2,41 USD to 7,22 for carrying out the addition measures. The diagonal of this matrix represent the R-square. The diagonal values suggest that 169 (39\%) respondents' WTP (out of of 434) are explained by the variables of the oprobit model. This value is not representative due to the high variance associated with CVM which tends to produce low R square. Mitchell and Carson (1989) recommend using a R-square higher that $15 \%$. As a result the predicted matrix result proofs the validity of the oprobit model and at the same time the significance of the variables chosen in regression $B$.
Table 8. Comparative matrix: predicted and observed WTP

\begin{tabular}{|c|c|c|c|c|c|c|c|c|c|}
\hline & \multicolumn{8}{|c|}{ Predicted } \\
\hline & & 1 & 2 & 3 & 4 & 5 & 6 & 7 & 8 \\
\hline \multirow{8}{*}{$\begin{array}{l}\widetilde{\Xi} \\
\stackrel{2}{2} \\
\tilde{\sigma} \\
0\end{array}$} & 1 & 1 & 0 & 1 & 7 & 3 & 0 & 0 & 0 \\
\hline & 2 & 0 & 0 & 0 & 5 & 5 & 0 & 0 & 0 \\
\hline & 3 & 1 & 0 & 1 & 30 & 14 & 0 & 0 & 0 \\
\hline & 4 & 0 & 0 & 1 & 63 & 59 & 0 & 1 & 0 \\
\hline & 5 & 0 & 0 & 0 & 46 & 93 & 0 & 4 & 0 \\
\hline & 6 & 0 & 0 & 0 & 11 & 30 & 0 & 4 & 0 \\
\hline & 7 & 0 & 0 & 0 & 5 & 29 & 0 & 9 & 2 \\
\hline & 8 & 0 & 0 & 0 & 0 & 2 & 0 & 5 & 2 \\
\hline
\end{tabular}

\begin{tabular}{|c|c|c|c|}
\hline 1 & wtp=0 & $\mathbf{5}$ & $\mathbf{4 , 8 1 < = w t p < 7 , 2 2}$ \\
\hline 2 & $0<w t p<0,96$ & $\mathbf{6}$ & $\mathbf{7 , 2 2 < = w t p < 9 , 6 2}$ \\
\hline 3 & $0,96<=w t p<2,41$ & 7 & wtp=9,96 \\
\hline 4 & $\mathbf{2 , 4 1 < = w t p < 4 , 8 1}$ & $\mathbf{8}$ & wtp $>9,96$ \\
\hline
\end{tabular}

Source: made by the author

\subsection{Cost benefit analysis}

The total value estimated by the CVM provides a relatively better picture of the benefits for protecting the Colombian Caribbean coast from SLR. This includes both direct and non-use value benefits. Consequently, after removing the outliers of the Max WTP variable, the protest vote bias values and strategic behaviour bias values, the mean respondents' Max WTP value can be extrapolated as the marginal benefit of carrying out the additional measures. In order to estimate the total benefit, the marginal benefit was multiplied by the number of households. As a result, the total benefit for 2007 for protecting the Colombian Caribbean Coast from SLR was estimated at 30'952,504.40 USD.

The cost of carrying out the additional measures of the protection strategy was estimated by the "Netherlands Climate Change Studies Assistance Programme-NCCSAP: Colombia" over a 100 year period (2001-2100) for each of the 3 cities in 2000 constant prices (INVEMAR, 2003). For this study the cost was adjusted to 2007 constant prices by using the inflation rate. The present value (PV) of 
the cost was given as 558'157.003 USD. Furthermore, to estimate the PV of the total benefit for a 94 year period (2007-2100) the assumption was made that the total benefits would remain constant for each year.

Table 9. Estimation of the PV of Net Benefit

\begin{tabular}{|l|r|}
\hline NPV Benefits & $784^{\prime} 603.038$ \\
\hline NPV Cost & $558^{\prime} 157.004$ \\
\hline NPV Net Benefit & $226^{\prime} 446.034$ \\
\hline
\end{tabular}

Source: made by the author

The results of the CBA for the period 20072100 show that the benefits of protecting the Colombia Caribbean Coast outweigh the cost (PV Net Benefit $>0$ ). This implies that carrying out the additional measures for protecting the Colombian Caribbean coast are viable to implement if sea level rise predictions are uncertain.

\section{CONCLUSIONS}

The response rate and consistency of the answers from surveys carried out in this study shows a high level of respondents' support for the additional measures to protect the Colombian Caribbean coast from SLR. In general, the results show a high degree of climate change and SLR awareness among the respondents. Relevant variables also influence the WTP similar to the study by Ng and Mendelsohn (2006) and others. These include, levels of income and education, the opinion about the consequences of SLR and climate change in Colombia, the number of years respondents have lived in the location, and the additional measures to protect the coast by the "Construction of the Artificial Reefs.". Respondents with children and those who have been living in the location for a longer period are less likely to be WTP for protection of the coast while respondents' married and with a high level of income and education are more likely to be WTP. In addition, respondents who think that the consequences of climate change and SLR in Colombia are "very serious" and the additional measures "Construction of the Artificial Reefs" must be implemented immediately were willing to pay more for protection of the coast.

Estimates of the WTP shows that majority of respondents were willing to pay 2,41 to 7,22 USD for carrying out the additional measures. This band may have been affected by the influence of the initial bid (starting point bias) in the WTP question which was 4,81 USD. In further studies this influence can be avoided by using spilt-sample techniques where different prices will be assigned to randomly selected respondents (Whittington, 1998). However, given the low incomes of the respondents the results may not be significantly different from the current outcome.

The total value estimated by the CVM helped to estimate of the benefits for protecting the Colombian Caribbean Coast from SLR including both the direct and non-use benefits. The Cost-Benefit Analysis shows that the benefits of protecting the Colombia Caribbean Coast outweigh the implementation cost. This implies that carrying out the additional measures for protecting the Colombian Caribbean Coast is viable to implement even if the SLR and its impacts are uncertain. As a recommendation for further studies, the uncertainty surrounding the consequences of sea level rise should be included.

It is hoped that the outcome of this study and its methodological approach would help the state and local governments to assess actions which would significantly reduce potential adverse impacts of SLR. Such protective measures may still be the wise thing to do even if projected effects of global warming fail materialise. However, the scarcity of resources in a developing country like Columbia must be taken into consideration in such decision. To carry out such additional measures, the local government should consider a joint strategy between public institutions, the private sector 
and international organizations. At the same time the government should create economic incentives for those institutions which are willing to carry out the protection plans.

\section{REFERENCIAS}

Chaudhry, Pradeep. Singh, Bilas and Tewari, Vindhya (2007). Non-market economic valuation in developing countries: Role of participant observation method in CVM analysis. In: Journal of Forest Economics, Vol.13, No 4, p. 259-275.

EPA -Environmental Protection Agency- (1995). Anticipatory planning for sea-level rise along the coast of Maine. Costs and Benefits of Selected Policy Response Options. Published September 1995 by the U.S. EPA Office of Policy, Planning, and Evaluation, 155p.

Gambarelli, Gretel and Goria, Alessandra (2004). Economic evaluation of climate change impacts and adaptation in Italy. [Online] The Fondazione Eni Enrico Mattei Note di Lavoro Series, lugar de publicacion, editor, July 2004, <http://papers. ssrn.com/sol3/papers.cfm?abstract_id=569122 >. [April, 2008]

Gibbs, Michael (1984). Economic analysis of sea level rise: methods and results. In: Michael C. Barth and James G. Titus, ed. Greenhouse effect and sea level rise: a challenge for this generation. Van Nostrand Reinhold Company Inc., Ch. 7, 29p.

Hanemann, W. Michael (1994). Valuing the environmental through contingent valuation. In: Journal of Economic Perspectives, Vol. 8, No 4, p. 19-43.

IDEAM -Institute of Hydrology, Meteorology and Environmental Studies- (2001). Colombia's First National Communication to the United Nation Framework Convention on Climate Change.

INVEMAR -Colombian National Institute for Marine and Coastal Research- (2003). Netherlands Climate Change. Studies Assistance Programme-NCCSAP: Colombia. Defining vulnerability of bio-geophysical and social-economic systems due to sea level change in Colombian coastal zone (Pacific and Caribbean) and adaptation measures.
Leary, Neil A. (1999). A framework for benefit-cost analysis o adaptation to climate change and climate variability. In: Mitigation and Adaptation Strategies for Global Change, Vol. 4, p. 307-318.

Mitchell, Robert C. and Carson, Richard T. (1989). Using surveys to value public goods: The Contingent Valuation Method. Resources for the Future, Washington, DC., 463p.

Magrin, Graciela; Gay García, Carlos; Cruz Choque, David; Giménez, Juan Carlos; Moreno, Ana Rosa; Nagy, Gustavo J.; Nobre, Carlos and Villamizar, Alicia (2007). Latin America. Climate Change 2007: Impacts, Adaptation and Vulnerability. Contribution of Working Group II to the Fourth Assessment Report of the Intergovernmental Panel on Climate Change, M.L. Parry, O.F. Canziani, J.P. Palutikof, P.J. van der Linden and C.E. Hanson, Eds.,Cambridge University Press, Cambridge, UK, p. 581-615.

Ng, Wei-Shiuen and Mendelsohn, Robert (2006). The economic impact of sea-level rise on nonmarket lands in Singapore. In: AMBIO: A Journal of the Human Environment, Vol. 35 No. 6, p. 289-296.

Pizer, William A. and Goulder, Lawrence H. (2005). The economics of climate change, Working Paper 11923. [Online] NBER Working Paper Series, Cambridge MA, National Bureau of Economic Research, January 2006, <http://www.nber.org/papers/ w11923.pdf>. [April, 2008].

Titus, James G. (1990). Strategies for adapting to the greenhouse effect. In: APA Journal 311, 13p.

Wattage, Premachandra; Smith, Andrew; Pitts, Colin; MacDonald, Adrian and Kay, David (2000). Integrating environmental impact, contigent valuation and cost-benefit analasis: empirical evidence for alternative perspective. In: Impact Assesment and Project Appraisal, Vol. 18, No 1, p. 5-14.

Whittington, Dale (1998). Administering contingent valuation surveys in developing countries. In: World Development, Vol. 26, No 1, p. 21-30.

Wooldridge, Jeffrey M (2002). Econometric analysis of cross section and panel data. MIT Press, Cambridge MA. 752p. 